\title{
The Impact of Title IX on Career Opportunities in Intercollegiate Athletic Administration
}

\author{
Glenna G. Bower \\ University of Southern Indiana \\ Mary A. Hums \\ University of Louisville
}

\begin{abstract}
The purpose of this study was to examine the impact of Title IX on the careers of men and women working in intercollegiate athletic administration. The participants $(N=1275)$ for this study were women $(n=497)$ and men $(n=778)$ working in intercollegiate athletic administration at NCAA Divisions I, II, II, as well as at NAIA schools and junior colleges. The participants completed the Female Sport Manager Career Survey and provided demographic and qualitative data. The primary impacts on careers described by the women in the study were (a) increased job opportunities for women, (b) no impact, and (c) increased opportunities for participation. The men, on the other hand, indicated the greatest impacts on careers as (a) no impact, (b) discrimination against qualified men, and (c) increased job opportunities for women. More research is needed to further examine these perceived impacts and how they affect the culture of an intercollegiate athletic department.
\end{abstract}

Keywords: Title IX, intercollegiate athletics, careers

The number of women in sport has dramatically increased since the passage of Title IX of the Education Amendments of 1972. According to the United States Department of Justice (n.d., Overview of Title IX section), "In June 1972, President Nixon signed Title IX of the Education Amendments of 1972 into law. Title IX is a comprehensive federal law that has removed many barriers that once prevented people, on the basis of sex, from participating in educational opportunities and careers of their choice." Title IX "prohibits discrimination based on sex in education programs that receive federal money" (Acosta \& Carpenter, 2012, p. iii). Institutions that are out of compliance with the statute potentially face loss of federal funding. The law has affected educational institutions, especially since 1978,

Bower is with the Dept. of Kinesiology and Sport, University of Southern Indiana, Evansville, IN. Hums is with Dept. of Sport Administration, University of Louisville, Louisville, KY. 
the "mandatory compliance date" for programs from elementary to high school and higher education. The "three prong test" is usually the most common way to measure if athletic programs at schools and universities are adhering to Title IX. Institutions need only meet one of these three prongs to be in compliance. To meet the first prong, an institution may demonstrate that men and women participate in athletics in numbers that are proportional to enrollment. To meet the second prong, an institution may demonstrate it has a history of increasing opportunities for underrepresented groups such as women. Finally, a school could meet the third prong by showing that it is meeting the needs and interests of it female student when it comes to athletic opportunities. Title IX includes all parts of educational programs including financial assistance, admissions, facilities, intramurals, and of particular importance to the researchers-intercollegiate athletics.

Most research on Title IX has focused on the impact of the legislation on opportunities for girls and women as participants, coaches, and administrators. This study takes a step in a different direction. In addition to surveying female athletic administrators on their perceptions of the impact of Title IX on their careers as women working in intercollegiate athletics, the researchers sought also examine the perceptions held by men as to impact the legislation had on them, specifically on their careers as men working in intercollegiate athletic administration. Hence, this study focused on the impact Title IX has made on the careers of women and men working within intercollegiate athletic administration.

\section{Title IX Impact}

To get a better grasp on Title IX's impact within intercollegiate athletics, a closer look at the legislation's impact on participation, coaching, and administration is warranted. The increase in the number of US girls' and women's sporting opportunities illustrates the biggest impact of Title IX. Acosta and Carpenter (2012) reported that the number of female athletes playing college sports has risen from 16,000 in 1968 to over 200,000 in 2012. The average number of women's teams per school has also grown from 2.5 in 1970 to 8.73 in 2012. Acosta and Carpenter (2012) speculated the potential reasons for this growth may include a "society's ability to embrace female athletes", "successful Title IX lawsuits", "another generation of post Title IX men and women who know now the benefits available from sport participation", and/or "increased media coverage" (p. 2). In addition to Acosta and Carpenter, other researchers have examined Title IX and its impact on participation, showing its positive influence throughout the years (Burton, 2009; Gewirtz, 2012; Jones, 2012; Kaestner, 2010; Office for Civil Rights, US Department of Education, 2012; Pauline, 2012; Stevenson, 2010; Yiamouyiannis, 2007).

Although the increased number of opportunities has provided women the chance to participate in sport, the percentage of women coaching women's teams has declined over time from $90 \%$ in 1972 to $42.9 \%$ in 2012 (Acosta \& Carpenter, 2012). Although $42.9 \%$ is a slight increase in the percentage of women coaching from the 2010 figure of $42.6 \%$, women still trail their male counterparts who coach $57.1 \%$ of the women's teams (Acosta \& Carpenter, 2012).

Alongside coaching is the lack of women working in intercollegiate athletic administration. In 1972, the percentage of female athletic directors overseeing women's programs was $90 \%$. Today, the percentage of female athletic directors 
is $20.3 \%$, a small increase from 2010 where women held $19.3 \%$ of administrative positions (Acosta \& Carpenter, 2012). There was also a small increase in the average number of female administrators for all Divisions (1.32-1.41), including Division I (1.71-1.78), Division II (1.08-1.24), and Division III (1.20-1.25). Again, researchers have examined how Title IX has played a role in the success of women obtaining leadership positions within intercollegiate athletic administration (Anderson, Cheslock, \& Ehrenberg, 2012; Beaubier, Gadbois, \& Stick, 2008; Hoffman, 2010; Quarterman, Dupree, \& Willis, 2006; Staurowsky, 2011; Whisenant, Pederson, \& Obenour, 2002). However, the number of females holding these positions has continued to be significantly lower than their male counterparts (Acosta \& Carpenter, 2012). In fact, at NCAA schools, there are currently 1415 male administrators compared with 598 female administrators for Division I; 617 male administrators compared with 362 female administrators for Division II; and 668 male administrators compared with 543 female administrators for Division III. These numbers equal 2700 male administrators in comparison with 1503 female administrators for all NCAA divisions. In addition, there are no female athletic administrators at $9.2 \%$ of schools across all NCAA divisions $(\mathrm{I}=1.3 \%$; $\mathrm{II}=8.6 \%$; $\mathrm{III}=15.6 \%)($ Acosta $\&$ Carpenter, 2012).

Of course, the numbers only tell part of the story. Reasons for this underrepresentation include, for example, discriminatory hiring procedures (Lovett \& Lowry, 1994), financial inequity (Acosta \& Carpenter, 2006; Pastore, 1991), work and career related variables (Hums, Bower, \& Grappendorf, 2007; Knoppers, 1989, 1992; Sagas \& Ashley, 2001; Sagas \& Cunningham, 2004; Yiamouyiannis, 2007), gender disparity (Kelly \& Sagas, 2005), and career-related burn-out (Pastore, 1991). While researchers have reported these various reasons for underrepresentation, the task remains as to how to overcome the challenges women face in pursuing careers in intercollegiate athletics. Title IX has been seen as providing the impetus for change.

Many studies support the impact of Title IX on participation (Acosta \& Carpenter, 2012; Stevenson, 2010) and coaching (Acosta \& Carpenter, 2012; Staurowsky, 2011). In addition, there is literature examining women working in intercollegiate athletic administration (Burton, Barr, Fink, \& Bruening, 2009; Burton, Grappendorf, \& Henderson, 2011; Hancock, 2012; Quarterman, Dupree, \& Willis, 2006). However, there are limited studies specifically examining the impact of Title IX on the careers of women working in leadership positions within intercollegiate athletic administration (Acosta \& Carpenter, 2012; Hoffman, 2010), and neither of these collected data from subjects on their personal perceptions of the impact of Title IX on their careers. There are even fewer or no studies exploring the impact of Title IX on men working in leadership positions within intercollegiate athletic administration. Title IX affects the entire culture of an intercollegiate athletic department, and that includes both men and women.

Throughout a person's professional career, events in an individual's external environment can impact one's career path. According to Duffy and Dik (2009, p. 33 ), one of these external influences is life circumstances, which includes "uncontrollable situations, events, and conditions that occur at an individual and societal level that may constrain career decision making." The passage of Title IX can be considered an event at the societal level which would impact the career paths of people working in intercollegiate athletics. 
Duffy and Dik (2009) go on to say "external influences are constraining, are out of the individual's control, and can significantly alter a given career path" (p. 38), and this impact can be either positive or negative. Therefore, the purpose of this study was to determine the impact Title IX had on career opportunities for both women and men working in intercollegiate athletic administration. This present study is the first to assess perceptions in this area in regards to men's attitudes in the sport industry and specifically about Title IX.

\section{Method}

\section{Participants}

The participants for this study were $1275(N=1275)$ women $(n=497)$ and men $(n=778)$ working in intercollegiate athletic administration at NCAA Divisions I, II, II, as well as at NAIA schools, and junior colleges. The research participants were selected based upon purposeful sampling. According to Rossman and Rallis (2003), purposeful sampling provides the researcher with "reasons (purposes) for selecting specific participants, events, processes" (p. 137). In this case, Title IX has had a strong impact on intercollegiate athletic administrators throughout the years (Acosta \& Carpenter, 2012; Hoffman, 2010). Since these participants were identified as intercollegiate athletic administrators, it may be likely they had a better conceptualization of Title IX due to their responsibilities related to compliance, resources, and other pertinent job duties. Maximal variation sampling (Creswell, 2008) was used as diverse individuals were chosen who were expected to hold different perspectives on Title IX (Creswell \& Clark, 2011). The criteria for maximizing those differences were division, age, ethnicity, salary range, and education. This array of participants was specifically chosen to provide an overall picture of Title IX from different perspectives.

The majority of the female participants in this study were (a) Division I (45.9\%), (b) Associate Athletic Directors (37.6\%), (c) age 45-54 years $(30.0 \%)$, (d) white $(87.5 \%)$, (e) paid a salary between $\$ 40,000-\$ 59,999$ per year $(30.2 \%)$, and (f) held a master's degree $(73.0 \%)$. The majority of the male participants in this study were (a) Division I (48.7\%), (b) Athletic Directors (34.4\%), (c) age 35-45 (32.3\%), (d) white $(86.5 \%)$, (e) paid a salary between $\$ 60,000-\$ 79,999(27.5 \%)$, and (f) held a master's degree $(66.7 \%)$. Table 1 provides additional demographic information for both men and women.

\section{Procedures}

Emails were sent to 6641 women $(n=1816)$ and men $(n=4318)$ working as athletic administrators at NCAA Divisions I, II, II, as well as at NAIA schools, and junior colleges. The emails directed participants to the survey which was set-up using Survey Monkey. The National Directory of College Athletics provided the e-mail addresses of the intercollegiate athletic administrators. After three weeks a follow up e-mail was sent to all nonrespondents. A total of 1275 usable surveys were returned for a return rate of $19.2 \%$. The usable surveys for women were 497 (27.4\% return rate) and the usable surveys for men were 778 (18.0\% return rate). 
Table 1 Demographics

\begin{tabular}{|c|c|c|}
\hline Division & Women & Men \\
\hline Division I & 228 & 379 \\
\hline Division II & 98 & 123 \\
\hline Division III & 122 & 137 \\
\hline NCCAA & 3 & 9 \\
\hline NAIA & 19 & 45 \\
\hline Junior College & 27 & 85 \\
\hline Position & Women & Men \\
\hline Athletic Director & 87 & 268 \\
\hline Associate Athletic Director & 187 & 267 \\
\hline Assistant Athletic Director & 144 & 209 \\
\hline Other & 75 & 02 \\
\hline Missing & 4 & 4 \\
\hline Age & Women & Men \\
\hline$<25$ & 2 & 3 \\
\hline $25-30$ & 40 & 57 \\
\hline $31-34$ & 66 & 75 \\
\hline $35-44$ & 147 & 251 \\
\hline $45-54$ & 149 & 212 \\
\hline 55 or above & 90 & 174 \\
\hline Missing & 3 & 6 \\
\hline Race/Ethnicity & Women & Men \\
\hline Native American & 2 & 4 \\
\hline Asian/Pacific Islander & 1 & 5 \\
\hline African American & 44 & 60 \\
\hline Hispanic & 4 & 18 \\
\hline White & 435 & 673 \\
\hline Other & 6 & 9 \\
\hline Missing & 5 & 9 \\
\hline Income Range & Women & Men \\
\hline Less than $\$ 19,999$ & 2 & 2 \\
\hline$\$ 20,000-\$ 39,999$ & 32 & 23 \\
\hline$\$ 40,000-\$ 59,999$ & 150 & 167 \\
\hline$\$ 60,000-\$ 79,999$ & 122 & 214 \\
\hline$\$ 80,000-\$ 99,999$ & 89 & 147 \\
\hline
\end{tabular}


Table 1 (continued)

\begin{tabular}{lcc}
\hline Division & Women & Men \\
\hline$\$ 100,000-\$ 119,999$ & 41 & 100 \\
$\$ 120,000-\$ 139,999$ & 36 & 44 \\
$\$ 140,000-\$ 159,999$ & 4 & 24 \\
$\$ 160,000-\$ 179,999$ & 5 & 11 \\
$\$ 180,000-\$ 199,999$ & 4 & 9 \\
$\$ 200,000$ or higher & 4 & 16 \\
Missing & 8 & 21 \\
\hline Degree & Women & Men \\
\hline High School Graduate & 2 & 0 \\
Some College (includes Associate) & 5 & 6 \\
College Graduate & 74 & 166 \\
Master's & 363 & 519 \\
Doctoral & 29 & 46 \\
JD & 19 & 26 \\
Other & 4 & 11 \\
Missing & 1 & 4 \\
\hline
\end{tabular}

One way to determine if respondents are representative of the population is to compare characteristics of the sample with the demographics in the literature (Olson, 2006). The respondents in this study were similar to those in work by Lapchick (2012), who found more than $80 \%$ of people working as intercollegiate athletic administrators were white. Male subjects in Sagas and Cunningham (2004) averaged 43 years of age and females 42 years. Female athletic administrators in Sagas and Cunningham's (2004) study had an average age of 42 and Hancock (2012) found the majority had a master's degree or higher. Another way to see if the respondents are representative of the population is by comparing early and late respondents. By Division, 52.1\%, 21.2\%, and $21.6 \%$ of early respondents came from Division I, II, and III respectively while $52.5 \%, 20.7 \%$, and $26.6 \%$ of late respondents came from NCAA Division I, II, and III respectively. These two groups were not significantly different.

\section{Instrument}

The Female Sport Manager Career Survey (Hums \& Sutton, 1999) was selected for this study. The initial instrument was examined by a panel of experts to make sure the instrument had content validity and avoided biased items and terms. The instrument was then pilot tested, and has since been used in studies involving women working in the management of professional baseball (Hums \& Sutton, 1999), professional basketball (Hums \& Sutton, 2000), sport for people with 
disabilities (Hums \& Moorman, 1999) and campus recreation (Bower \& Hums, 2003). The initial survey focused on career paths and concerns of women working in management positions in professional sport. Appropriate modifications of the survey language were made for this study to address both men and women working in intercollegiate athletic administration.

The questions for the Female Sport Manager Career Survey included demographic information of age, educational background, income, and race. The survey also included a number of open-ended questions about women's careers in intercollegiate athletics. For this study, the qualitative responses to the question "What impact did Title IX have on your career opportunities in intercollegiate athletic administration?" were analyzed using content analysis.

\section{Data Analysis}

For this descriptive study, frequencies were calculated for the demographic data using SPSS 19.0. A content analysis was used for the qualitative data. A content analysis is "any technique for making inferences by systematically and objectively identifying special characteristic of messages" (Holsti, 1968, p. 608). From this perspective, "any items that can be made into text are amendable to content analysis" (Berg, 2007, p. 240). The data were organized by using the research software HyperResearch 2.6 (ReserachWare, Inc., 2013). HyperResearch 2.6 assists in coding and retrieving, building theories and conducting analysis of the responses to open-ended questions (ResearchWare, Inc., 2013). The software also allows for quantitative tallying to determine certain frequencies of relevant categories. Both researchers were trained in the use of HyperResearch 2.6. HyperResearch 2.6 was a reliable statistical procedure that provided assistance in the consistency of coding (Creswell, 2009). For intercoder agreement (cross-checking), a fellow researcher who was also trained in using HyperResearch 2.6 and familiar with coding, examined the codes to assist the researchers when there was a disagreement. The consistency in coding was in agreement at least $80 \%$ of the time, the recommended number for good qualitative reliability (Miles \& Huberman, 1994).

Wolcott's (1994) four-step approach assisted in the organization of the data analysis. First, the researchers organized the data by uploading all the qualitative responses into HyperResearch 2.6. Second, the researchers read and reread the qualitative responses from the open-ended questions. This inductive approach allowed both researchers to become immersed in the participant comments.

Third, before category development, the researchers decided to use phrases as samples to determine what unit of analysis would be counted. For classification purposes, phrases were used because some sentences contained two or more divergent ideas. For example, the comments "increased leadership positions for females. .." and "increased leadership positions for males" were grouped under "increased leadership positions." Each phrase was assigned to a single category. The categories cultivated into "working with people" which captured the group meaning of the comments (Weber, 1990). Categories were determined though an inductive method to identify the dimensions that seemed meaningful to the message. This allowed the researchers to link the categories to the data. Themes were the one major element counted in the written messages. According to Berg (2007), the "theme is a more useful unit to count" (p. 246). 
Finally, analyses of the various concepts and categories were completed after both researchers completed open coding. HyperResearch 2.6 allowed the researchers to select any group of comments and apply any number of code names to the comments (HyperResearch, Inc, 2013). Throughout the process, the researchers used Strauss' (1987) four basic guidelines when conducting the open coding. These guidelines included: (a) focusing on the data specific to the research questions, (b) analyzing the date in great detail, (c) interrupting the coding process to write theoretical notes as needed, and (d) making no assumptions on the analytic relevance of variables until the data show it to be relevant.

Content analysis was accomplished through the use of coding frames. These coding frames were used to "organize the data and to identify findings after open coding has been completed" (Berg, 2007, p. 253). Strauss (1987) indicated that "axial coding occurs after open coding is completed and consists of intensive coding around one category" (p. 253). Therefore, the researchers used constant comparative analysis as the categorical strategy of analysis to "identify similarities and differences among the data through coding and sorting into appropriate categories" (Rallis, 2011, p. 273) and grouped comments with similar meaning.

The researchers narrowed down the total number of comments by deleting the stand-alone comments made by single participants. The rationale was to delete these comments from further analysis because the researchers were more interested in comments in which multiple participants shared common experiences. The analysis was completed through reading and rereading the comments and concluded with a content analysis and interpreting the patterns apparent from the details offered in responses to the open-ended questions. This allowed the researchers to think about the data and questions that led to the emergence of plausible answers.

\section{Trustworthiness of the Data}

The researchers used multiple strategies introduced by Lincoln and Guba (1985) to strengthen the trustworthiness of the study. The credibility (internal validity) was strengthened through the use of constant comparative analysis by establishing categories and developing themes from the open-ended questions. The constant comparative analysis allowed for "authenticity" which is described by Neuman (2010), as a "fair, honest, and balanced account of social life from the viewpoint of someone who lives it every day" (p. 31).

Transferability (external validity) was provided by examining the comments from the intercollegiate athletic administrators to support the themes (Erlandson, Harris, Skipper, \& Allen, 1993). The "thick" description of some of the responses provided the researchers with the setting and provided discussion on the elements of the shared experiences.

Dependability (reliability) was provided by transcript evaluation and research debriefing or cross-checking. Transcripts were checked to eliminate any mistakes that were made during the transcription process. In addition, each researcher examined the data and met to discuss themes and categories. The final list of themes and categories were determined following the meeting.

Confirmability (objectivity) was based on the researchers' ability to limit bias by not making any premature conclusions on the themes and/or categories, by reading and rereading the data, using the constant comparative analysis, and the researchers debriefing. 


\section{Results and Discussion}

The purpose of this study was to determine the impact Title IX had on career opportunities for both women and men working in intercollegiate athletic administration. Understanding the impact Title IX had on these individuals may provide women and men greater insight on how important Title IX has been and continues to be in an effort to achieve gender equity. Two of the top three themes were mentioned by both male and female participants and are discussed together (increased opportunities for women and no impact). The remaining two themes (discriminatory hiring and increased opportunities to participate in sport) are discussed separately. Additional results may be found in Tables 2 and 3 .

\section{Increased Opportunities for Women}

Both women (\#1 theme) and men (\#2 theme) mentioned Title IX provided additional opportunities for women. The women indicated this response most often when asked the impact Title IX had on career opportunities within intercollegiate athletic administration while men mentioned it as their second theme. However, the literature provides a different outlook on career opportunities within intercollegiate athletics for women and men. One may say Title IX did not impact career opportunities for women within leadership positions but did impact career opportunities for men according to the statistics presented throughout this paper, as men hold 2700 administrative positions compared with 1503 held by women in intercollegiate athletics (Acosta \& Carpenter, 2012). Some men tended to support this statistic of men having an increased opportunity for jobs by saying,

Because of Title IX I am currently in this position. My baseball career was cut short because of Title IX. Instead of adding more female sports at my university they cut men's sports including baseball. So I focused on Academics and got a job sooner than I thought I would.

An explanation that may support the increased opportunities for women is the establishment of the Senior Woman Administrator (SWA) in 1981. SWAs have created leadership role opportunities for women who have the obligation of bringing Title IX issues to the attention of the department. Basically, the title was established to provide women active involvement with administrative responsibilities, along with decision-making at the institutional, conference, and national levels (Hoffman, 2010). Several comments were mentioned to support how the establishment of the SWA may have impacted the increase in opportunities for women. For example, a woman mentioned, "Title IX directly led to my first SWA position after the NCAA required institutions to have the position." Another woman mentioned,

Certainly the SWA title helped me get to the table which helped people to realize I should be at the table. I imagine that even though we still have a long way to go, without it I would not have progressed enough in administration to have kept me interested.

Men commented as well on the SWA position and the increased opportunities it provided for women. One male respondent wrote, "Some jobs were closed off to me because they were seeking a female to assume the role of SWA in addition to 


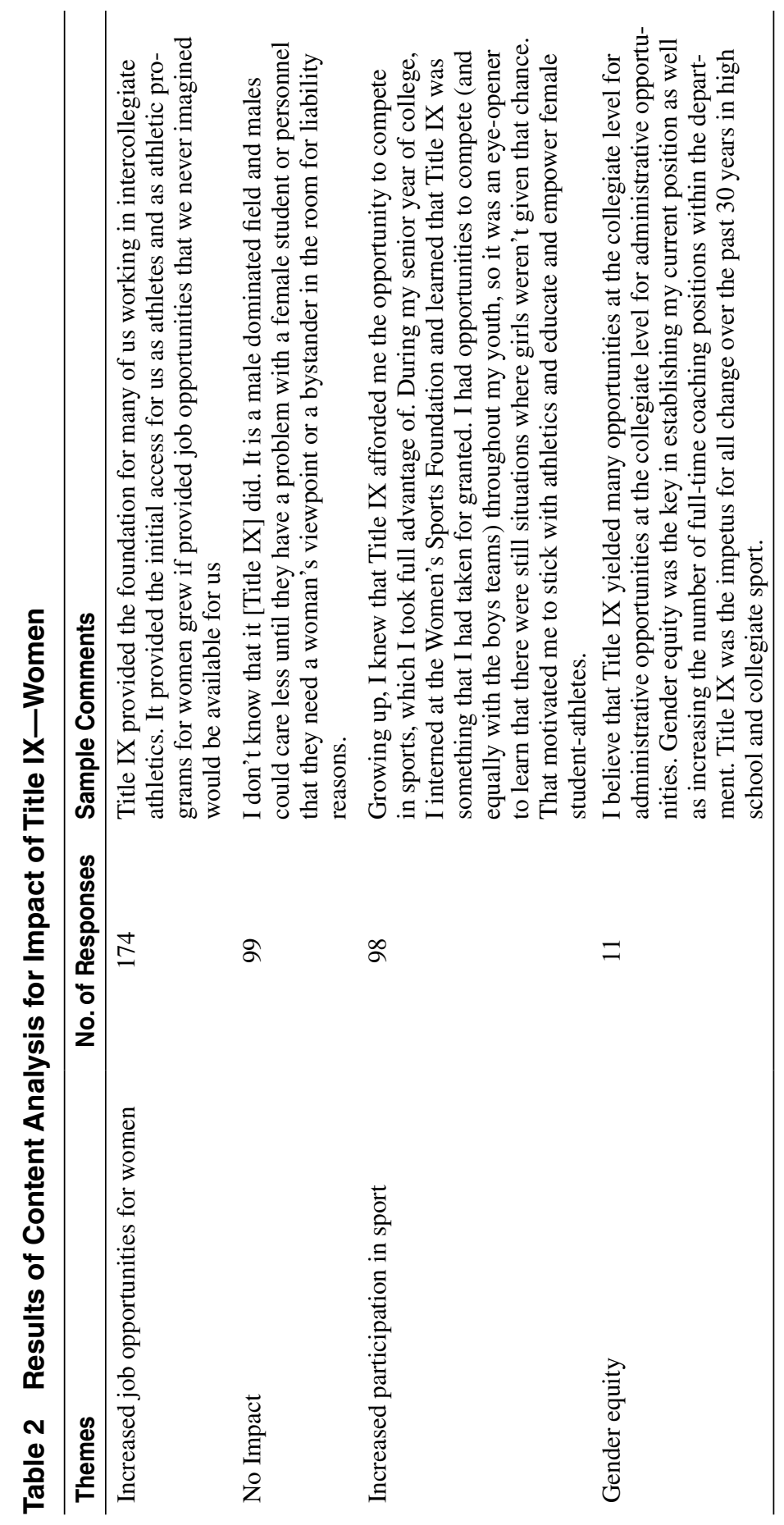




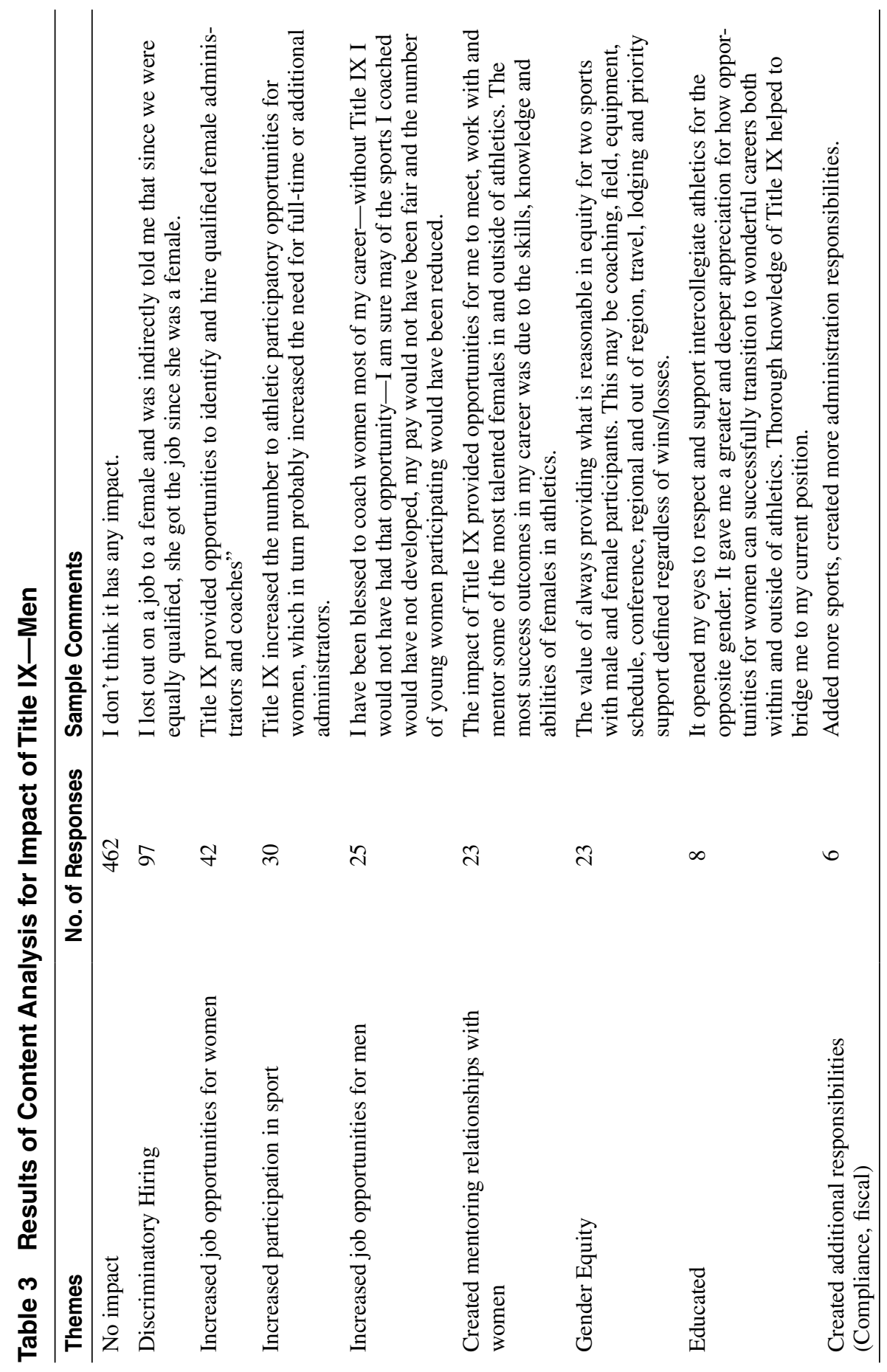


the open position." Another man mentioned, "The requirement of having an SWA on staff has cost me the opportunity for a couple of jobs." These responses may also support the second most common theme most often mentioned by the men as discriminatory hiring. This theme is discussed later in the paper.

\section{No Impact}

Both women (\#2 theme) and men (\#1 theme) mentioned Title IX had no impact on their career opportunities. There may be several possibilities for why the women and men answered this way. For women, the responses focused on pre-Title IX explanations such as, "I am not aware of the impact of Title IX [on my career opportunities]. I don't know that I was alive when it was adopted." Another participant mentioned, "Hard to know as I entered well after Title IX." Other responses were related to the institution. For example, some of the women were from Christian colleges and responded, "Very little since I have always worked in a Christian college setting." Other women worked at all women's colleges and said, "None that I am aware of since our institution is a women's college."

Some of the comments from the men reflected pre-Title IX issues such as, "I can't possibly know if or how things would've been different for me as an athletic administrator due to Title IX because it was not of my era." Another man mentioned it had no impact on his career but on participation, "It [Title IX] has not had an impact on me from an opportunity standpoint. It has reinforced my belief that it is the right thing to do as I want my daughter to have the same opportunities as my sons have enjoyed." Finally, pre-Title IX comments from the men may have been mentioned due to not being exposed to discriminatory hiring. For example, a man replied, "To be honest I don't think it has had an impact on my career path because I have never been in a position where I was a finalist for a job with a woman."

\section{Increased Opportunities to Participate in Sport}

One other area that received a greater number of responses from women (\#3 theme) than men (\#4 theme) was that Title IX increased opportunities to participate in sport. For example, a woman responded,

Growing up, I knew that Title IX afforded me the opportunity to compete in sports, which I took full advantage of. During my senior year of college, I interned at the Women's Sports Foundation and learned that Title IX was something that I had taken for granted. I had opportunities to compete (and equally with the boys' teams) throughout my youth, so it was an eye-opener to learn that there were still situations where girls weren't given the chance. That motivated me to stick with athletics and educate and empower female student-athletes.

As the remarks read, one would have to speculate how this relates to career opportunities, which is the focus on this study. Logically, it seems that the women may be referring to the fact that increased opportunities to participate in sport led to an increased opportunity for jobs. A woman supported this explanation by saying, "I had the opportunity to compete as a scholarship athlete as a result of Title IX. It also contributed to the opportunity to pursue a career in intercollegiate athletics." Another woman supported the comment by saying, 
Athletics were my entry point into every job that I have ever had. Title IX was passed just as I was entering upper elementary school, so I was that first generation to really benefit from the doors that Title IX opened. I was able to play volleyball on a full athletic scholarship which led into a coaching career and from there, athletic administration. I don't know what I would be doing now if I hadn't had these opportunities to participate.

In addition, the literature supports an increase in participation of women. Acosta and Carpenter (2012) reported that the number of female athletes playing college sports has risen from 16,000 in 1968 to over 200,000 in 2012. The number of women's teams per school has also grown from 2.5 in 1970 to 8.73 in 2012. Does this really mean that job opportunities improved because of participation? Both women and men responded "yes" to an increase in career opportunities. On the other hand, the men also believed the increase in the number of career opportunities have led to discriminatory hiring (\#2 theme) which is the next theme discussed.

\section{Discriminatory Hiring}

Male participants indicated Title IX resulted in discriminatory hiring (\#3 theme) as athletic administrators needed to hire more women, eliminating men from the pool even if they were more qualified. For example, a man commented on discriminatory hiring by saying,

Universities are too willing to hire a woman with less experience and education than a male counterpart just to show that they can stay in compliance with Title IX. I love the idea, but the application leaves something to be desired.

Another man said, at a previous employer, "I was passed over for a senior position in my office because there were no females on our staff so they hired the position twice before I got the job and both times it was a woman."

According to the literature, the discriminatory responses may be the perception that Title IX and gender equity requirements are responsible for the loss of many intercollegiate athletic men's teams (Bensen, 2007; Ridpath, Yiamouyiannis, Lawrence, \& Galles, 2008; Ridpath, 2007a; 2007b) which has led to allegations of reverse sex discrimination. A man said,

People think that everything has to be the same proven by numbers. Title IX is more than that and those that only view numbers as the reason for its existence are missing the boat on what its intent really is. Sometime equality does NOT mean equal numbers, or budgets, because for some sports and in some situations, that creates reverse discrimination.

Although the men were adamant about discriminatory hiring, another look at the numbers may be an indication that there are still not enough women in leadership positions with 2700 male administrators compared with 1503 female administrators for all divisions. In addition, 9.2\% of NCAA institutions do not have a female administrator (Acosta \& Carpenter, 2012).

For example, data at the NCAA Division I level suggest that women currently occupy just $8.7 \%$ of head athletic director positions despite the fact that they occupy over $40 \%$ of the student-athlete participation offerings at this level (Acosta \& 
Carpenter, 2002). Female administrators are also underrepresented in lower level administration positions (e.g., associate athletic director, assistant athletic director) and are outnumbered by male administrators at this level by a ratio of over 3-1 (Acosta \& Carpenter, 2002).

\section{Implications and Future Research}

The purpose of this study was to determine the impact Title IX had on career opportunities for both women and men working in intercollegiate athletic administration. It seems the only disagreement between the women and men in this study was whether men were discriminated against because they are male. The women (174 responses) in the study focused their attention on increased career opportunities. A total of 42 responses from the men agreed. However, more men responded that Title IX created discriminatory hiring (97 responses). More specifically, women may have been hired to comply with Title IX where institutions demonstrated they had a history of increasing opportunities for underrepresented groups such as women. Discriminatory hiring appears in the literature outside of the sport industry in terms of reverse discrimination in employment whether based on gender or race (Busby, 2006; Maryl \& Saperstein, 2013; Sabbagh, 2011). This present study is the first to assess perceptions in this area is regards to men's attitudes in the sport industry and specifically about Title IX. Certainly, there is evidence of perceived bias against men's sports such as wrestling or baseball being cut under the premise of implementing Title IX. This study did not look at dropping of teams, but rather looked at the perceptions of administrators and the impact of Title IX on their personal career paths.

Second, future researchers should focus attention on women who are SWAs to see how Title IX has actually impacted their career opportunities. Are unqualified women being hired due to the ramifications of Title IX and the SWA title? For example, some respondents in Hancock's (2012) study found that holding the SWA title helped some women serve on NCAA committees, allowing them networking opportunities which could result in career advancement. Other respondents felt making the SWA title a career goal limited women's advancement.

Third, both women (98 responses) and men (30 responses) indicated there was an increase in career opportunities for women due to an increase in participation. Researchers should focus attention on whether the increased participation in intercollegiate athletics has led to additional positions within intercollegiate athletic administration. In addition, researchers should also focus on the qualifications of women and men during the hiring process.

Once interesting result that is rather surprising is the total number of women (11) and men (8) that mentioned the term gender equity in relation to how it impacted their career opportunities. Gender equity is a large component of Title IX. It may be related to the research on compliance issues in terms of adhering to Title IX. Research indicates it is not the law, but rather the implementation of the law, that is the issue (Causby, 2010; Office of Civil Rights, 2012). Future researchers should focus their attention on examining the perceptions of women and men on the degree to which issues surrounding gender equity exist within intercollegiate athletics. 


\section{Conclusion}

The results of the study brought about some interesting responses to consider when it comes to the impact Title IX had on the career opportunities of women and men working in intercollegiate athletic administration. The primary impacts on careers described by the women in the study were (a) increased job opportunities for women, (b) no impact, and (c) increased opportunities for participation. The men, on the other hand, indicated the greatest impacts on careers as (a) no impact, (b) discrimination against qualified men, and (c) increased job opportunities for women. More research is needed to further examine these perceived impacts and how they affect the culture of an intercollegiate athletic department.

\section{References}

Acosta, R. V., \& Carpenter, L. J. (2002). Acosta-Carpenter study shows decline in female AD's, coaches. Athletic Management, 14(4), 10-11.

Acosta, R.V., \& Carpenter, L.J. (2006). Women in intercollegiate sport: A longitudinal, national study twenty-nine year update 1997-2006. Retrieved from http://www.womenssportsfoundation.org/cgibin/iowa/issues/part/article.html?record=117

Acosta, R.V., \& Carpenter, L.J. (2009). Are we there yet? Academe Online. Retrieved from http://acostacarpenter.org/AAUP_\%20Are\%20We\%20There\%20Yet.pdf

Acosta, R.V., \& Carpenter, L.J. (2012). Women in intercollegiate sport: A longitudinal, national study, thirty-five year update, 1977-2012. Retrieved from http://www.acostacarpenter.org

Anderson, D., Cheslock, J., \& Ehrenberg, R. (2012). Gender equity in intercollegiate athletics: Determinants of Title IX compliance. Retrieved from http://courses. Washington. edu/pbafadv/title\%20nine.pdf.

Beaubier, D.M., Gadbois, S.A., \& Stick, S.L. (2008). Canadian athletic directors' perceptions of the potential for U.S. Title IX gender equity policy. Journal of Issues in Intercollegiate Athletics, 1(1), 46-73.

Bensen, D. (2007, October 8). Taking a hit: While women's programs flourished under Title IX, men's athletics suffered. Fort Wayne News Sentinel. Retrieved from http:// fwnextweb1.fortwayne.com/ns/projects/title9/title910.php.

Berg, B.L. (2007). Qualitative research methods for social sciences (6th ed.). Boston, MA: Allyn and Bacon.

Bower, G.G., \& Hums, M.A. (2003). Women working in the administration of campus recreation. NIRSA Recreational Sports Journal, 27(2), 35.

Burton, L. (2009). A reinvigorated call for support of Title IX at the high school level. Journal of Physical Education, Recreation \& Dance, 80(8), 4-5. doi:10.1080/07303 084.2009.10598364

Burton, L., Barr, C.A., Fink, J., \& Bruening, J. (2009). "Think athletic director, think masculine": Examination of the gender typing of managerial subroles within athletic administration positions. Sex Roles, 5/6, 416-426. doi:10.1007/s11199-009-9632-6

Burton, L., Grappendorf, H., \& Henderson, A. (2011). Perceptions of gender in athletic administration: Utilizing role congruity to examine (potential) prejudice against women. Journal of Sport Management, 25(1), 36-45.

Busby, N. (2006). Affirmative action in women's employment: Lessons from Canada. Journal of Law and Society, 33(1), 42-58. doi:10.1111/j.1467-6478.2006.00346.x

Causby, C.S. (2010). Title IX compliance at two-year colleges: An analysis of perceived barriers and strategies. Unpublished dissertation, Western Carolina University. 
Compton, N.H., \& Compton, D.J. (2010). How Title IX and proportionality population concepts have equalized collegiate women's sports programs with men's sports and allows spillover gains for women in the workplace. Forum on Public Policy Online, 2010(2), 2010.

Creswell, J.W. (2008). Research design: Qualitative, quantitative, and mixed methods approaches (3rd ed.). Thousands Oaks, California: Sage Publications, Inc.

Creswell, J.W., \& Clark, V.L.P. (2011). Designing and conducting mixed methods research (2nd ed.). Thousands Oaks, CA: Sage.

Duffy, R., \& Dik, B. (2009). Beyond the self: External influences in the career development process. The Career Development Quarterly, 58, 29-43. doi:10.1002/j.2161-0045.2009. tb00171.x

Earlandson, D.A., Harris, E.L., Skipper, B.L., \& Allen, S.D. (1993). Doing naturalistic inquiry: A guide to methods. Beverly Hills, CA: Sage.

Gewirtz, J. (2012). Significant moments in women's sports since Title IX. Sportstravel, 16(5), 10-15.

Hancock, M. (2012). Women in intercollegiate athletics: An exploration of the career development of female senior administrators. Unpublished dissertation University of Louisville.

Hoffman, J. (2010). The dilemma of the senor woman administrator role in intercollegiate athletics. Journal of Issues in Intercollegiate Athletics, 3, 53-75.

Holsti, O. R. (1968). Content analysis. The handbook of social psychology. Reading, MA: Addison-Wesley.

Hums, M.A., Bower, G.G., \& Grappendorf, H. (2007). Women as leaders in sport: Impact and influence. Oxon Hill, MD: AAHPERD Publications.

Hums, M.A., \& Moorman, A.M. (1999, July). Women working in the management of Sport for people with disabilities: Complex issues. Paper presented at the $50^{\text {th }}$ anniversary conference of the International Association of Physical Education \& Sport for Girls and Women, Northampton, MA.

Hums, M.A., \& Sutton, W.A. (1999). Women working in the management of professional baseball: Getting to first base? Journal of Career Development, 26(2), 147-158.

Hums, M.A., \& Sutton, W.A. (2000, June). Women working in the management of professional basketball: Career paths and challenges. Paper presented at the annual conference of the North American Society for Sport Management, Vancouver, BC, Canada.

Jones, C. (2012). Getting in the game: Title IX and the women's sports revolution. Marquette Sports Law Review, 22(2), 613-618.

Kaestner, R. (2010). Title IX, girls' sport participation, and adult female physical activity and weight. Evaluation Review, 34(1), 52-78. PubMed doi:10.1177/0193841X09353539

Kelly, S.J., \& Sagas, M. (2005). Gender disparities in career outcomes of assistant coaches: Discrimination or capital deficiencies. Applied Research in Coaching \& Athletics Annual, 20, 94-118.

Knoppers, A. (1989). Coaching: An equal opportunity occupation? Journal of Physical Education, Recreation \& Dance, 60(3), 38. doi:10.1080/07303084.1989.10603969

Knoppers, A. (1992). Explaining male dominance and sex segregation in coaching: Three approaches. Quest, 44(2), 210-227. doi:10.1080/00336297.1992.10484051

Lapchick, R. (2012). 2012 racial and gender report card. Retrieved from http://www.bus. ucf.edu/sport/public/downloads/2012_Racial_Gender_Report_Card.pdf.

Lincoln, Y. S., \& Guba, E. G. (1985). Naturalistic inquiry. Beverly Hills, CA: Sage.

Lovett, D. J., \& Lowry, C. D. (1994). "Good old boys" and "good old girls" clubs: Myth or reality? Journal of Sport Management, 8(1), 27-36.

Maryl, D., \& Saperstein, A. (2013). When white people report racial discrimination: The role of region, religion and politics. Social Science Research, 42(3), 742-754. PubMed doi:10.1016/j.ssresearch.2012.12.007

Miles, M.B., \& Huberman, A.M. (1994). Qualitative data analysis: A sourcebook of new methods. Thousand Oaks, CA: Sage. 
Neuman, W.L. (2010). Social research methods: Qualitative and quantitative approaches (7th ed.). Boston, MA: Allyn and Bacon.

Office of Civil Rights. US Department of Education. (2012). Gender equity in education: A data snapshot. Retrieved from http://www2.ed.gov/about/offices/list/ocr/index. html? $\mathrm{src}=\mathrm{OC}$

Olson, K. (2006). Survey participation, nonresponse bias, measurement error bias, and total bias. Public Opinion Quarterly, 70(5), 737-758. doi:10.1093/poq/nfl038

Pastore, D.L. (1991). Male and female coaches of women's teams: Reasons for entering and leaving the profession. Journal of Sport Management, 5, 128-143.

Pauline, G. (2012). Celebrating 40 years of Title IX: How far have we really come? Journal of Physical Education, Recreation \& Dance, 83(4), 4-7. doi:10.1080/07303084.201 2.10598818

Quarterman, J., Dupree, A.D., \& Willis, K.P. (2006). Challenges confronting female intercollegiate athletic directors of NCAA member institutions by division. College Student Journal, 40(3), 518-546.

Rallis, S.F. (2011). Learning in the field: An introduction to qualitative research (3rd ed.). Thousand Oaks, CA: Sage Publications.

ResearchWare, Inc. (2013). HyperResearch. Retrieved from http://www.researchware.com/ products/hyperresearch.html

Richman, R. (2011). Title IX: The Trojan horse in the struggle for female athletic coaches to attain equal opportunities in intercollegiate sports. Virginia Sports \& Entertainment Law Journal, 10(2), 376-413.

Ridpath, B.D. (2007a). April). Confessions of a former wrestling coach regarding the application of Title IX and the sport of wrestling. Washington, DC: United States Department of Education Office of Civil Rights.

Ridpath, B.D. (2007b, Fall). Factors that influence the academic performance of NCAA Division I athletes. Sport Management and Related Topics Journal (SMART), IV(1). Retrieved from http://www.thesmartjournal.com/volume4.htm.

Ridpath, B.D., Yiamouyiannis, A., Lawrence, H., \& Galles, K. (2008). Changing sides: The failure of the wrestling community's challenges to Title IX and new strategies for saving NCAA sport teams. Journal of Intercollegiate Sports, 1(1), 255-283.

Rossman, G. B., \& Rallis, S. F. (2003). Learning in the field: An introduction to qualitative research (2nd ed.). Thousand Oaks, CA: Sage Publications.

Sabbagh, D. (2011). The paradox of decentralization: Deinstitutionalizing race through ace based affirmative action in the United State. Ethnic and Racial Studies, 34(10), 1665-1681. doi:10.1080/01419870.2011.569029

Sagas, M., \& Ashley, F.B. (2001). Gender differences in the intent to leave coaching: The role of personal, external, and work-related variables. International Journal of Sport Management, 2, 297-314.

Sagas, M., \& Cunningham, G.B. (2004). Does having the "right stuff" matter? Gender differences in determinants of careers success among intercollegiate athletic administrators. Sex Roles, 50(5/6), Retrieved from http://link.springer.com/article/10.1023\%2FB\%3AS ERS.0000018895.68011.fa?LI=true\# page-1. doi:10.1023/B:SERS.0000018895.68011.fa

Staurowsky, E. J. (2011). The role of Title IX coordinators in fostering Title IX literacy among NCAA coaches and administration. Journal of NCAA Compliance, May/June, 8.

Staurowsky, E.J., \& Weight, E.A. (2011). Title IX literacy: What coaches don't know and need to find out. Journal of Intercollegiate Sport, 4(2), 190-209.

Stevenson, B. (2010). Beyond the classroom: Using Title IX to measure the return rate to HS sport. Retrieved from http://www.nber.org/papers/W15728.

Strauss, A.L. (1987). Qualitative analysis for social scientists. New York: Cambridge University Press.

United States Department of Justice. (n.d.). Title IX legal manual. Retrieved from http://www. justice.gov/crt/about/cor/coord/ixlegal.php\#II.\%C2\%A0\%C2\%A0\%20Synopsis\%20 
of $\% 20$ Purpose $\% 20$ of $\% 20$ Title\%20IX, \%20Legislative\%20History, \%20and $\% 20$ Regulations

Weber, R.P. (1990). Basic content analysis (2nd ed.). Newbury Park, CA: Sage.

Whisenant, W., Pederson, P., \& Obenour, B. (2002). Success and gender: Determining the rate of advancement for intercollegiate athletic directors. Sex Roles, 47(9/10), 485-491. doi:10.1023/A:1021656628604

Wolcott, H.F. (1994). Transforming qualitative data: Description, analysis, and interpretation. Thousand Oak, CA: Sage.

Yiamouyiannis, A. (2007). Occupational closure in intercollegiate athletics: Female head coaches of men's sport teams at NCAA colleges. Unpublished doctoral dissertation, George Washington University, Washington, DC. 